\title{
Pengaruh Kompetensi Dan Beban Kerja Terhadap Perilaku Perawat Dalam Menerapkanasuhan Keperawatan Profesional Di Instalasi Rawat Inap RSUD Praya
}

\author{
Menap, Teguh Achmalona \\ Email: edysurya31@gmail.com
}

Universitas Qamarul Huda Badaruddin, NTB, Indonesia

\begin{abstract}
ABSTRAK
Pelayanan keperawatan merupakan bagian integral dari pelayanan kesehatan yang mempunyai posisi sangat stategis dalam upaya meningkatkan kualitas pelayanan di rumah sakit.Dengan kondisi iniseorang perawat dituntutmemiliki kemampuan serta profesionalisme dalam menerapkan asuhan keperawatan professional yang ada di sebuah pelayanan rumah sakit.Tujuan penelitian ini adalah untuk mengetahui pengaruh faktor kompetensi, dan beban kerja terhadap perilaku perawat dalam menerapkanasuhan keperawatan professional di instalasi rawat inap RSUD Praya.Desain penelitian yang digunakan adalah analitik kuantitatif dengan pendekatan cross sectional. Tehnik pengambilan sampel menggunakan Cluster random sampling dengan sampel sebanyak 114 responden. Data dikumpulkan menggunakan kuesioner dan lembar observasi, kemudian dianalisis menggunakan uji regresi ordinal. Hasil penelitian dari uji statistik secara stimultan diperoleh nilai p value sebesar $0,000<\alpha=0,05$, artinya semua variabel independen secara bersama-sama mempengaruhi variabel dependen. Sedangkan dari hasil uji statistik secara parsial untuk masing-masing variabel diperoleh hasil yaitu kompetensi ( $\mathrm{p}<$ $0,008)$ dan beban kerja $(\mathrm{p}<0,012)$. Analisis multivariat menunjukkan kompetensi merupakan variabel paling dominan yang mempengaruhi perilaku perawat dalam menerapkan asuhan keperawatan profesional dengan nilai $(\mathrm{p}<0,008)$. Perilaku perawat dalam menerapkan asuhan keperawatan professional di rumah sakit dipengaruhi oleh beberapa faktor diantaranya kompetensi dan beban kerja.Aspek-aspek tersebut tentunya perlu diperhatiakn dan dikelola dengan baik dengan harapan untuk mendapatkan hasil kinerja perawat yang lebih baik demi terciptanya pelayanan keperawatan yang maksimal.
\end{abstract}

Kata Kunci: Kompetensi, Beban Kerja, Perilaku Perawat,Asuhan Keperawatan

\begin{abstract}
Nursing services are an integral part of health services which have a very strategic position in an effort to improve the quality of services in hospitals. With this condition a nurse is required to have the ability and professionalism in implementing professional nursing care in a hospital service. The purpose of this study was to determine the effect of competency factors, and workload on nurses' behavior in implementing professional nursing care in the Praya Hospital inpatient installation. The research design used was quantitative analytic with cross sectional approach. The sampling technique uses cluster random sampling with a sample of 114 respondents. Data were collected using a questionnaire and observation sheet, then analyzed using the ordinal regression test. The results of the statistical test by stimulatory results obtained $\mathrm{p}$ value of $0,000<\alpha=0.05$, meaning that all independent variables together affect the dependent variable. While partial statistical test results for each variable obtained results, namely competency ( $p<0.008)$ and workload $(p<0.012)$. Multivariate analysis showed competence was the most dominant variable influencing the behavior of nurses in applying professional nursing care with a value $(\mathrm{p}<0.008)$. The behavior of nurses in implementing professional nursing care in hospitals is influenced by several factors including competency and workload. These aspects certainly need to be considered and managed well in the hope of getting better nurse performance results for the creation of maximum nursing services.
\end{abstract}

Keywords: Competence, Workload, Nurse Behavior, Nursing Care 


\section{A. LATAR BELAKANG}

Rumah sakit merupakan salah satu sarana upaya kesehatan yang memberikanpelayanan dalam bidang kesehatan kepada masyarakatc dan memiliki peran yang strategis dalam rangka peningkatan derajat kesehatan masyarakat. Oleh karena itu, rumah sakit selalu dituntut untuk memberikan pelayanan yang bermutu sesuai dengan standar yang telah ditetapkan.

Pelayanan keperawatan adalah bagian integral dari pelayanan kesehatan yang ada di rumah sakit, yang mempunyai posisi sangat stategis dalam upaya meningkatkan kualitas pelayanan yang ada.Pelayanan keperawatan sering dijadikan tolak ukur citra sebuah rumah sakit di mata masyarakat, sehingga menuntut adanya profesionalisme perawat pelaksana maupun perawat pengelola dalam memberikan dan mengatur kegiatan asuhan keperawatan kepada pasien.

Menurut Gibson, individu seorang perawat dipengaruhi oleh 3 variabel yaitu variabel individu, variabel organisasi dan variabel psikologis. Variabel individu terdiri dari kemampuan, atau keterampilan yang dimiliki, pengetahuan, demografi dan latar belakang keluarga.Variabel psikologi terdiri dari persepsi, sikap, motivasi, kepribadian dan belajar.Variabel organisasi terdiri dari sumber daya, imbalan, beban kerja, struktur, supervisi dan kepemimpinan.

Rumah Sakit Umum Derah (RSUD) Praya adalah rumah sakit type $\mathrm{C}$ yang ada di Kabupaten Lombok Tengah dengan kapasitas 279 tempat tidur dengan jumlah tenaga keperawatan dari bulan Desember 2017 ialah sebanyak 276 orang. Dengan rincian 109 orang berstatus pegawai negeri sipil (PNS) dan 167 orang berstatus pegawai tidak tetap (PTT). Data yang ada menunjukkan jumlah BOR dari 75,3\% pada tahun 2017. Sedangakn untuk tingkat kepuasan pasien terhadap pelayanan keperawatan hanya $70 \%$, angka tersebut masih di bawah standar mutu yang ditetapkan oleh manajemen rumah sakit yaitu sebesar $80 \%$.Keluhan tersebut paling banyak terkait dengan perilaku perawat dalam memberikan pelayanan keperawatan yang dirasa masih sangat kurang yang menimbulkan ketidakpuasan pasien terhadap kualitas pelayanan.

Jika hal tersebut dibiarkan tentunya akan memiliki dampak yang negatif terhadap citra dan kinerja dari sebuah rumah sakit.

\section{B. METODE PENELITIAN}

Penelitian ini menggunakan metode analitik kuantitatif dengan menggunakan pendekatan cross sectional. Populasi dalam penelitian ini berjumlah 160 orang perawat yang bertugas dan terlibat dalam pemberian asuhan keperawatan di instalasi rawat inap RSUD Praya. Besar sampel dalam penelitian berjumlah 114 responden dengan menggunakan tehnik cluster random sampling. Variabel independen dalam penelitian ini adalah kompetensi, dan beban kerja perawat.Sedangkan variabel dependent pada penelitian ini adalah perilaku perawat.Data dikumpulkan menggunakan kuesioner dan lembar observasi, kemudian dianalisis menggunakan uji regresi ordinal.

\section{HASIL DAN PEMBAHASAN}

Penelitian ini dilakukan pada tanggal 12-24 Mei 2018 di instalasi rawat inap RSUD Praya dengan jumlah sampel sebanyak 114 orang.Tujuan penelitian ini adalah untuk mengetahui pengaruh faktor kompetensi, dan beban kerja terhadap perilaku perawat dalam menerapkanasuhan keperawatan professional di instalasi rawat inap RSUD Praya.Setelah data dikumpulkan kemudian diolah secara komputerisasi.

\section{Analisa Univariat}

Berdasarkan tabel 1. dari 114 responden terdapat 61 responden $(53,5 \%)$ berada pada kelompok umur 26-30 tahun, 69 responden $(60,5 \%)$ diantaranya berjenis kelamin laki-laki. 50 responden $(43,9 \%)$ memiliki pendidikan ners. 82 responden $(71,9 \%)$ memiliki masa kerja kurang dari 10 tahun. 
Tabel 1. Distribusi karakteristik responden berdasarkan umur, jenis kelamin, pendidikan, dan masa kerja di RSUD Praya

\begin{tabular}{|c|l|c|c|}
\hline No. & Karakteristik & Frekuensi & $\begin{array}{c}\text { Persentase } \\
(\mathbf{\%})\end{array}$ \\
\hline 1 & Umur & \\
\hline & $<25$ & 15 & 13,2 \\
& $26-30$ & 61 & 53,5 \\
& $31-35$ & 38 & 33,3 \\
\hline 2 & Jenis kelamin \\
\hline & Laki-laki & 69 & 60,5 \\
& Perempuan & 45 & 39,5 \\
\hline 3 & Jenis pendidikan \\
\hline & Ners & 50 & 43,9 \\
& SI & 35 & 30,7 \\
& DII & 29 & 25,4 \\
\hline 4 & Masa kerja & 82 & 71,9 \\
\hline & $<10$ & 32 & 28,1 \\
\hline
\end{tabular}

Tabel 2. Distribusi karakteristik variabel berdasarkan kepemimpinan, kompetensi, motivasi, reward dan perilaku di RSUD Praya

\begin{tabular}{|c|l|c|c|}
\hline No & Karakteristik & Frekuensi & Persentase \\
\hline 1 & Kompetensi \\
& \multicolumn{2}{|l|}{} \\
\hline & Kurang & 12 & 10,5 \\
& Cukup & 83 & 72,8 \\
& Baik & 19 & 16,7 \\
& \multicolumn{2}{|l}{} \\
\hline 2 & Beban kerja & 3,5 \\
& Rendah & 4 & 71,1 \\
& Sedang & 81 & 25,4 \\
& Tinggi & 29 & 20,2 \\
\hline 3 & Perilaku & 23 & 51,8 \\
& Kurang & 59 & 28,1 \\
& Cukup & 32 & \\
& Baik
\end{tabular}

Berdasarkan tabel 2 diatas dari 114 responden terdapat 83 responden $(72,8 \%)$ kompetensi perawat cukup, 81 responden $(71,1 \%)$ memiliki beban kerja sedang, 59 responden $(51,8 \%)$ perilaku perawat cukup.

\section{Analisis Multivariat}

Hasil uji statistik secara simultan diperoleh nilai $\mathrm{p}$ value sebesar $0,000<\alpha=0,05$, artinya semua variabel independen secara bersama-sama mempengaruhi variabel dependen. Hasil uji statistik secara parsial dengan taraf signifikan $\alpha$ $=0,05$ didapatkan hasil ada pengaruh antara kompetensi dan beban kerja dengan perilaku perawat. Nilai $\mathrm{p}$ value untukmasing-masing variabel yaitu kompetensi $(p<0,008)$, beban kerja $(\mathrm{p}<0,012)$.

Table 3. Pengaruh kompetensi dan beban kerja terhadap perilaku perawat dalam menerapkanasuhan keperawatan professional di Instalasi Rawat Inap RSUD Praya.

\begin{tabular}{|c|c|c|c|c|c|}
\hline \multicolumn{6}{|c|}{ Coefficients $^{a}$} \\
\hline \multirow{2}{*}{$\begin{array}{l}\bar{\nabla} \\
\bar{\delta} \\
\Sigma\end{array}$} & \multicolumn{2}{|c|}{$\begin{array}{l}\text { Unstandardized } \\
\text { Coefficients }\end{array}$} & $\begin{array}{l}\text { Standar } \\
\text { dized } \\
\text { Coeffic }\end{array}$ & \multirow[t]{2}{*}{$\mathrm{T}$} & \multirow[t]{2}{*}{ Sig. } \\
\hline & $\boldsymbol{B}$ & $\begin{array}{c}\text { Std. } \\
\text { Error }\end{array}$ & Beta & & \\
\hline $\begin{array}{l}\text { Con } \\
\text { stant }\end{array}$ & 585 & ,332 & & 1,763 & ,081 \\
\hline $\mathrm{X} 1$ & 262 & , 198 & ,189 & 1,323 & ,008 \\
\hline $\mathrm{X} 2$ & ,396 & , 155 & ,282 & 2,553 & ,012 \\
\hline
\end{tabular}

\section{Pengaruh Kompetensi Terhadap Perilaku Perawat Dalam Menerapkan Asuhan Keperawatan Professional Di Instalasi Rawat Inap RSUD Praya}

Berdasarkan hasil analisis regresiordinal variabel kompetensi memiliki nilai $\mathrm{p}$-value $=$ $0,008<\alpha=0,05$ sehingga H0 ditolak dan H1diterima. Berdasarkan nilai p-value tersebut maka dapat dijelaskan bahwa ada pengaruh kompetensi terhadap perilaku perawat dalammenerapkan asuhan keperawatan professional di instalasi rawat inap RSUD Praya

Kompetensi berkaitan dengan kemampuan melaksanakan pekerjaan atau tugas yang didasari ketrampilan maupun pengetahuan dan didukung oleh sikap kerja yang ditetapkan oleh pekerjaan.Kompetensi yang dimiliki oleh seorang perawat meliputi kemampuan intelektual, fisik dan hubungan antar manusia yang menjadi dasar bagi perawat dalam melaksanakan asuhan keperawatan. Artinya, jika seorang perawat memiliki kompetensi yang baik maka dalam menjalankan tugasnya akan memberikan dampak yang baik bagi pasien dan keluarga, dan sebaliknya jika seorang perawat 
memiliki kompetensi yang kurang maka dalam menjalankan tugasnya akan memberikan dampak kurang baik untuk pasien.

Sehingga dalam menjalankan dan melaksanakan kegiatan pelayanan keperawatan, seorang perawat dituntut menggunakan ilmu pengetahuan dan teori yang ada dalam ilmu keperawatan serta dapat dipertanggungjawabkan demi tercapainya tujuan pelayanan yang maksimal.Itulah sebabnya kompetensi yang dimiliki seorang perawat dalam memberikan pelayanan keperawatan adalah sesuatu yang wajib dimiliki dan dikuasai oleh seorang perawat di dalam proses pemberian asuhan keperawatan

\section{Pengaruh Beban Kerja Terhadap Perilaku Perawat Dalam Menerapkan Asuhan Keperawatan Professional Di Instalasi Rawat Inap RSUD Praya}

Berdasarkan hasil analisis regresiordinal variabel beban kerja memiliki nilai $\mathrm{p}$-value $=$ $0,012<\alpha=0,05$ sehingga H0 ditolak dan H1diterima. Berdasarkan nilai p-value tersebut maka dapat dijelaskan bahwa ada pengaruh beban kerja terhadap perilaku perawat dalammenerapkan asuhan keperawatan professional di instalasi rawat inap RSUD Praya

Beban kerja adalah kemampuan tubuh pekerja dalam menerima pekerjaan.Setiap beban kerja yang diterima seseorang harus sesuai dan seimbang dengan kemampuan fisik maupun psikologis pekerja yang menerima beban kerja tersebut. Menurut Kurniadi A. (2013), yang mempengaruhi beban kerja perawat adalah kondisi pasien yang selalu berubah, jumlah ratarata jam perawatan yang di butuhkan untuk memberikan pelayanan langsung pada pasien dan dokumentasi asuhan keperawatan, serta masih banyaknya tugas tambahan yang harus dikerjakan oleh seorang perawat sehingga dapat mempengaruhi kinerja perawat tersebut.

Jika seseorang berada dalam lingkungan kerja yang beban kerjanya tinggi kemungkinan besar orang tersebut tidak menghasilkan kinerja yang memuaskan bahkan bisa menimbulkan kejenuhan. Untuk itu perlu dilakukan upaya penyerasian antara kapasitas kerja, beban kerja dan lingkungan kerja agar diperoleh produktivitas kerja yang optimal yang pada akhirnya akan memberikan dampak yang positif terhadap kualitas pelayanan yang ada.

\section{KESIMPULAN}

Berdasarkan hasil penelitian dapat disimpulkan ada pengaruh antara kepemimpinan, kompetensi, motivasi, beban kerja dan reward dengan perilaku perawat.reward merupakan variabel paling dominan yang mempengaruhi perilaku perawat dalam memberikan pelayanan keperawatan

Saran dari penelitian ini antara lain:

\section{Bagi RSUD Praya}

Bagi pihak manajemen Rumah Sakit, dalam menyusun strategi pelayanan kesehatan khususnya pelayanan keperawatan hendaknya memperhatikan aspek-aspek yang bisa berpengaruh dengan perilaku perawat. Aspek tersebut harus dikelola dengan baik dengan harapan untuk mendapatkan hasil kinerja dan perilaku perawat yang lebih baik dan dijadikan sebagai satu dasar upaya preventif terkait dengan kualitas layanan yang ada di rumah sakit tersebut.

\section{Bagi Peneliti Selanjutnya}

Bagi peneliti selanjutnya diharapkan dapat mengembangkan penelitian ini dengan melakukan penelitian tetang faktor-faktor yang mempengaruhi perilaku perawat yang belum diteliti oleh peneliti yaitu supervisi.

\section{DAFTAR PUSTAKA}

[1] Budiawan,2016. Hubungan Kompetensi, Motivasi Dan Beban Kerja Dengan Kinerja Perawat Pelaksana Di Ruang Rawat Inap Rumah Sakit Jiwa Provinsi Bali

[2] Hani handoko. 2012. Manajemen personalia dan sumber daya manusia. BFFE, Yogyakarta

[3] Hasmoko EV. Analisis Faktor-Faktor Yang Mempengaruhi Kinerja Klinis Perawat Berdasarkan Penerapan Sistem Pengembangan Manajemen Kinerja Klinis Di Ruang Rawat Inap Rumah Sakit Panti 
Wilasa Citarum Semarang [Tesis]. Semarang: Universitas Diponegoro; 2012.

[4] Herwyndianata, Balqis, Darmawansyah. Analisis Faktor Yang Berhubungan Dengan Kinerja Perawat Dalam Penerapan Standar Asuhan Keperawatan Di Unit Rawat Inap RSU Anuta pura Palu tahun 2013. Makassar: Universitas Hasanudin; 2013.

[5] Kepmenkes No.129 tahun 2008 tentang Standar Pelayanan Minimal RS

[6] Kurniadi, Anwar. (2013). Manajemen Keperawatan dan Prospektifnya : Teori dan Aplikasi. Jakarta. Fakultas Kedokteran Universitas Indonesia
[7] Martono, Nanang. 2012. Metode Penelitian Kuantitatif : Analisis Isi danAnalisis Data skunder, Ed. Revisi. Jakarta: Rajawali Pers

[8] Profil Rumah Sakit Umum Daerah Praya tahun 2017.

[9] Menap, (2017) Caring Dalam Keperawatan, Maghza Pustaka, Yogyakarta

[10] Sudirman. 2013. "Hubungan Beban Kerja dengan Kinerja Perawat Pelaksana di Ruang Rawat Inap Instalasi Penyakit Dalam RSMH Palembang” (Tesis). Palembang. 